\title{
Phenomenological Description of Classical Music as an Ethnos-Forming Element of Yakut Culture
}

\author{
Yuliya C. Zamaraeva* \\ Siberian Federal University \\ 79 Svobodny, Krasnoyarsk, 660041, Russia
}

Received 27.08.2014, received in revised form 19.10.2014, accepted 16.01.2015

\begin{abstract}
The classic professional musical art of Yakutia has become a clear distinctive artistic phenomenon since 1990's. This fact indicates that the professional musical art of Yakutia is a relatively young musical culture. In this paper a number of sources on the history of classical music serve as a material for the analysis and study of the current state of classical music art, revealing specific features of classical music as an ethnos-forming element of Yakut culture. Meanwhile, this area of knowledge at present time is ripe for a substantial research, according to scholars; the fundamental (analytical and synthetic) investigations on music culture are practically absent. To date, there is a number of essential requirements for strengthening and development of its own mechanisms of self-education and self-preservation of the core culture of the northern territories. In its final part the paper contains recommendations on governmental cultural policies, which assist in maintaining distinctive cultural traditions of the circumpolar area.
\end{abstract}

Keywords: musical culture of Yakutia, cultural studies, cultural studies, ethnicity.

Research area: culture studies, art history.

\section{The History of Classical Music} in Yakutia

According to the sources on the history of Yakut classical music in the 40 -ies of $20^{\text {th }}$ century there was made an extrapolation of the musical canons of European type on the musical stage circumpolar areas, which contributed to familiarizing national culture to musical professionalism. The process of organization of professional music education in Yakutsk region begins in 1944. The following objectives were selected as innovations: establishment of a school of composers, music educators and performing arts. Along with oral folk music, there was an attempt to create professional composers and musicians. Moreover, a real opportunity to provide music education to the younger generation appeared. The need for this historic innovation likely was a result of the fact that in the first half of the $19^{\text {th }}$ century survived a few details on pianos in Yakut houses and concert performances of individual numbers ("solo on the piano") at the beginning of the $20^{\text {th }}$ century. Nevertheless, we have little data to judge about the quality and level of the performances. One should be very cautious when speaking about musical culture of Yakutia in the $19^{\text {th }}$ - early $20^{\text {th }}$ centuries. A need to bring Russian and European music emerged.

(C) Siberian Federal University. All rights reserved

* Corresponding author E-mail address: rybka08@bk.ru 
The general picture of the musical culture of Yakutia of the first twenty years of the $20^{\text {th }}$ century was the following: at the beginning of the century choir singing emerges, musical amateurs appear. In 1920 a Symphony Orchestra already exists, and in 1921 an educational and music studio was opened. The activity of the section of "Admirers of music and literature" contributed to promoting Russian European culture for a certain part of the indigenous population of the city. However the values of European and Russian music influenced only a small portion of the urban population, for the concerts were held only in Yakutsk. Most of the inhabitants of Yakutia continued to meet their aesthetic needs only by the means of traditional art. In 1929 a radio center appeared. It was used as an information center and a mechanism for mass notification of the northerners. In 1936 a choir at Yakutsk Theater (under the supervision of M.N. Zhirkov) was formed. Thus, for the first three decades of the 20th century was created a minimal but necessary set of musical events and special institutions for teaching how "to listen" to choral singing and attempts to perform (training studio as an experimental platform), broadcast to the mass audience of the Far North. Afterwards, according to the preserved data, in the 40s some Moscow professors were invited in order to create a number of musical works based on the Yakut folklore. In this connection, there was a need for masterful technical and performance skills of specialists for "processing" and new interpreting of the musical basis of Yakut culture. A number of national operas and ballet works were created ("Nyurgun Bootur", "Wildflower", "Crimson Scarf" et al.). The opening of a music school in 1949 revealed a desire to educate students who absorbed the tendency to preserve the unique music on the basis of professional classical art. The first teacher-pianist of the indigenous group with higher education appeared only in 1960 (A.A. Popov), and the first professional Yakut composer in 1970s (Z.K. Stepanov).

Since the 1930s Yakutia has had a group of musicians who have come from the central cities of Russia and all this time have been working in the field of professional piano performance. It was this time when the gradual process of inclusion of the national culture in the worldwide culture started. However, national piano schools emerged much later, when in the mid-1960, the piano repertoire was formed and the first professional indigenous pianists appeared. The first concert pianist of the Sakha people was M.M. Sleptsov; he performed solo and symphony concerts. Thus, in the period from the 1930s to the 60s in the field of classical music the emergence of a national music based on the synthesis of professional performing arts of the European level and folk music arts of the circumpolar areas took place. Simultaneously an active propaganda of the national music was used and it contributed to the formation of future professional performance skills in the Yakut musical culture.

In 1960s the trend of piano playing continued to grow, as in 1964 the Urban Youth Philharmonic was established; its activity constituted an important reservoir of musical life in Yakutsk. Dramatic art was based on the activities of Yakut theater; the theater made productions that promoted uniqueness of the historical and cultural themes of the northern territories ("Lookut and Nyurgusun", "Flower of the North", etc.). Themes of the National Ballets contributed to this tendency ("Stone of Happiness", "Joy of Altan", "Northern Lights" and others.). The basis of the symphonic music is formed by program music works: cantatas, poems, symphonies, and suites. Yakut national holidays and tools form the plot basis: Symphonic Rhapsody "Ysyakh. Yakut holiday" (1964 G.I. Litinsky), "Concert improvisation for the khoomei and Orchestra" 
(1972, N.S. Berastov, featuring the khoomei performer I.E. Alekseev).

$70-90$ years of $20^{\text {th }}$ century were the time when the professional classical music Yakut art was established: honored artists and artists of the RSFSR worked on the territories; there were conductors, choirmasters, composers of melodies. Evenings of Yakut music in other cities of Russia were particularly beloved (since 1974); its participants were popular honored artists and singers of ASSR of the RSFSR. A whole range of musical institutions operated on the territory of Yakutia: Musical Theatre (1982), the symphony orchestra and the choir of the Committee for Television and Radio, Philharmonic, a folk dance company, the House of Folk Art, Union of Composers, eighty four music schools. History of folklore in Yakutia can be traced by the exhibits of unique musical instruments in the museum of music and folklore of the peoples of the Sakha Republic (Yakutia), as well as in the international center of khoomei and Jew's harp. The concert activity of piano music became more detailed in comparison with the previous years, at times the number of solo concerts increased - the result of education of students in the depths of music schools and colleges of the Yakut ASSR, the purpose of which was the promotion of classical music. A special role was played by professional educators of Sakha people in piano music, who had been educated in Russia's central institutions and now were involved in the formation of the national piano art. The main purpose of the teachers became to get the folklore traditions embodied in musical performance as a special contribution to the multinational Russian culture.

According to the study of A.V. Varlamova the basic ethnos-forming elements of classical music of Yakutia are the following:

These elements are the basis for the creation of national samples of music; and for them
European musical traditions remain to be a "tuning fork".

\section{The Current State of Classical Music in the Republic of Sakha (Yakutia)}

This part describes the institutions and events representing the classical music of Yakutia at modern times. The main concentration of educational and performing arts and music today can be found in the Higher School of Music of the Sakha Republic, which was opened in 1992 and which continues to operate as an integrated multi-level university, created by a unique project "Canadian Village" (students living in comfortable cottages on the territory of a suburban campus).

In its structure, the Higher School of Music is a music and a secondary school, a college and a higher musical institution. According to the concept, the Higher School of Music functions as a center of musical education Sakha Sire, consistent with current trends in higher education in Russia. These five levels of special training of musicians: beginner, intermediate, two higher and highest (Higher School of Excellence) provide consistent training according to criteria for higher educational achievements of modern musical performing arts.

The concept of the Higher School of Music implies the following main objectives:

The ongoing project in the Far North conditions is unique because in addition to the understanding that only through classical music the Yakut ethnic education in contemporary culture may be preserved, the Higher School of Music maintains the historical and contemporary practice of education of artists with exceptional musical talents.

The structure of the teaching staff is organized in a hierarchical manner, whereby the leading professors of faculties (four professors working in shifts) select teachers on a contract 


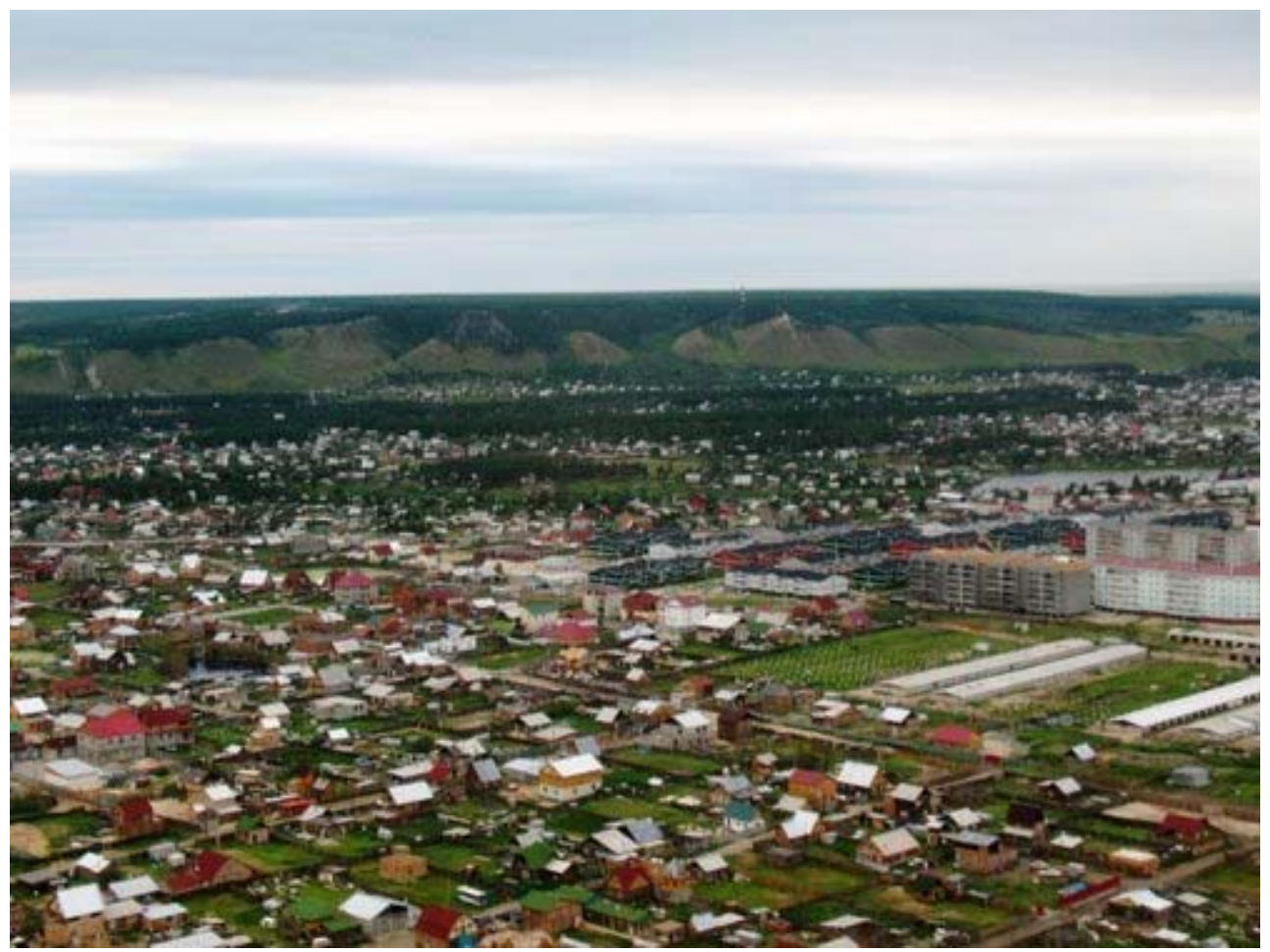

Fig. 1. Photo by Nikolay Filippov

basis from musical institutions of Russia and the CIS (12-15 people) and assistants (about twenty young musicians of the Republic). The following subjects are studied:

The basic principle for teachers living with their children is the development of the personality of the child, the maximum disclosure of creativity and preparation for entry into the life of society. The patterns of education are implemented in accordance with the global experience of educating the younger generation. The main system-forming factors of the educational system are the following: a cognitive component, club activities and a component of socio-cultural development. Thus, the strategy chosen for the education of the younger generation is similar to the processes of incubator nurturing of gifted children who can not only focus on achieving heights in the field of classical music, but also can be prepared for the process of socialization within the Yakut society. It is noteworthy that the musical and educational project implemented at the Higher School of Music becomes an effective ethnos-forming technology. The goals and objectives of the Higher School of Music reflect not a desire to become a part of a multinational state (a strategy of assimilation into the culture of the dominant society), but a desire to preserve itself as a unique ethnic formation on the territory of the Far North. On the one hand, the classical music becomes an ethnos-forming element, since it is based on the concept of preservation of folk traditions in the world adopted to the forms of classical music. On the other hand, constructing the whole process of education on the traditions of classical music the people of Yakutia use this common basis in order to represent themselves to the surrounding world. The classical music is chosen as a method of self-representing as an autonomous and fully independent culture. This 
fact is clearly stated in the objectives of school: 1) Development of the needs of children in knowledge; 2) The development of self-awareness; 3) An introduction to the leading spiritual values of the people, citizenship education; 4) The development of needs in a healthy lifestyle; 5) The harmonization of relations in the schoolwide collective; 6) Formation of the public opinion on important issues of life, society and human relations.

Therefore, at present time a targeted construction of the new culture is taking place, through the powerful motivation of young people and providing full comprehensive education (including financial, economic, logistical, scientific and methodological, etc.). Invitations to teach and conduct workshops sent to worldfamous classical musicians, folk artists and soloists are considered an effective way of training. The purpose of this form of education is to demonstrate the highest achievements in the field of classical music. Another form of learning is to organize creative schools on the basis of the Higher School of Music, in which the teachers of the organization "New Times" conduct master classes.

The structure of musical institutions of the Republic of Yakutia is the following: Yakutsk College of Culture and Arts (opened in 1937), Orchestra and Chorus of the Yakutsk State Opera and Balle named after Suorun Omolloon, Yakutsk College of Music named after M.N. Zhirkov (opened in 1949), Arctic State Institute of Art (established on 17 January 2000), the State Philharmonic of the Republic of Sakha (Yakutia), opened January 01, 2011. The musical groups of the Republic of Yakutia include: Composers' Union (founded in 1979), State vocal group "Tuymaada" (established in 1987), the State ensemble of violinists of the Sakha Republic (Yakutia) "Virtuosos of Yakutia" (1994). The main charity funds, contributing to the development of classical music in the Republic of Sakha (Yakutia) are: International Charitable Foundation "New Names" (established in 1989), the International Fund "Children of Sakha - Asia". One of significant cultural institutions is a museum of music and folklore of the peoples of Yakutia (opened in 1990, and in 1991 it was converted into a republican museum; in 1999 it entered into the Register of public cultural institutions). Important composers in the history of classical music of Yakutia are: M.N. Zhirkov, G.A. Grigoryan, G.N. Komrakov, E.E. Alekseev, G.I. Litinsky, N.S. Berestov, Zh.A. Batuev, V.G. Katz, V.M. Bocharov, V.V. Ksenofontov, N.I. Peyko, N.I. Bazhov, L.V. Vishkarev, Z.K. Stepanov, Z.P. Vinokurov, Kh.T. Maximova, S.F. Pavlova, G.M. Nikiforova, O.P. Ivanova. Significant musical events now are the following: a) "Rainbow of the North" Interregional Competition of instrumentalists of M.N. Zhirkov, under accompanied by the State Concert Orchestra of Yakutia; b) "Northern Lights" - an international festival of music dedicated to the International Day of Music and Public Forum "Society's Spiritual Potential in the Innovative Development of Yakutia"; c) "Musical Yakutsk" - concerts of United Republic musical groups (State Opera and Ballet Theatre of Sakha (Yakutia) named after. D.K. Sivtsev, State Philharmonic of Sakha (Yakutia), the Higher School of Music of Sakha (Yakutia), Arctic State Institute of Art and Culture, Yakutsk College of Music named after M.N. Zhirkov); d) Symphony Concert Orchestras of the Higher School, under the baton of the leading conductors of Moscow, Japan, Italy etc. The professional journal "Yakutia music serves as a means of information notification about musical events in the Republic. The journal provides coverage of major music events in the country. The founders of the journal are the High School of Music and the Office of the educational institutions of the 
Ministry of Culture and Spiritual Development of the Republic of Sakha (Yakutia).

\section{Conclusion}

Over the past two decades, the field of classical music and culture resumed its functioning as a social mechanism of cultural self-organization of the Yakut ethnic group. This shows, on one hand, a marked influence of the external pressure of the civilizational processes on the reproduction of culture of the peoples of the circumpolar area. On the other hand, it refers to the process of preserving the identity of the Yakut culture in modern times; it tries to attach its unique existence to the world cultural space. In the 1920's to the 90's the classical music in Yakutia was formed in accordance with the strategy of "melting pot" in which the specificity of the northern regional music had to be mastered and reinforced by the traditions of the European level of performance. In 1920-40-ies a trend of merging the national folk music of Yakutia and European traditions of performing appeared; it was an attempt to preserve the core part with the help of classical instruments (piano, wind instruments, classical choral singing). In 1940-60-ies there was a reflection of the features of the Yakut folklore by professional performers of classical art in Moscow material ballet and opera repertoire. In 1960-80-ies there are national performers of folk music in classical programming genres, the main theme was the history and identity of the people of specificity of the northern life in the circumpolar territories. The main events that were broadcasted outwardly were Yakut evenings of music and piano concerts. Inside the territory musical and cultural museums and facilities were created; they were used as one of conservation technologies for song and music. The established musical institutions became "responsible" for comprehensive education and nurturing of Yakut professionals who, in turn, became responsible for maintaining songs and instrumental folk music of Yakutia as a ethnos-forming element of the culture. Schools of Russian music composers, piano, string, bow, and other schools provided assistance in training and education of artists, composers and teachers, who helped to create the identity and integrity of the modern musical art that can be titled "Yakut professional music".

In modern times we can clearly see the Yakut tendency of ethnos-forming through comprehensive holistic musical education of the young generation, who are supposed (ideally) be virtuoso performers of folk music; connoisseurs of ethnic music of the North Asia; translators of ideals of the unique continental northern musical culture adapted to the generally accepted traditions of musical genres in the civilized world. Meanwhile, the conditions for preventing the young Yakut specialists from migration outside the Northern Territory were created. Firstly, the absence of migration is due to the organized system of educational institutions for targeted high-quality training of musicians. Second, actively supported international cooperation with Western European countries (the organization of competitions and master classes interchange), created an opportunity to study in schools in leading Russian universities and then return and work in the musical institutions of the Republic. In connection with these facts, the Yakut classical music from the turn of $20^{\text {th }}-21^{\text {st }}$ centuries and currently acts as the most effective mechanism of ethnos-forming culture of the northern peoples.

Modern Music and performing arts, built on the basis of a classical system of music education and the current through the close relationship between Yakutsk leading music institutions created as a single ethnos-preserving cultural space. A vivid example of this is the experiment of the Higher School of Music (Canadian Village), which helps to create an intense, individualoriented vocational training for musically 
gifted children, who become raised with the knowledge of themselves as an integral part of the multinational northern region of the country. The patterns of providing education for teachers make students in particular to be culturally plunged into the unique space of the circumpolar area and, at the same time, prepare them for the process of national socialization. Thus, the Yakut classical music builds relationships to the world and European civilization by high achievements in the field of professional performing arts in the future and the expected new wave of creative activity in this area. The role of a "bridge" (or "conductor") here is played by the Russian culture, because since the $60 \mathrm{~s}$ of the $20^{\text {th }}$ century, many composers and performers have contributed into broadcasting the achievements of Yakut musicians to the cultural space of the world civilization. To date, there is a number of essential needs for enhancing the production of its own mechanisms of self-education and self-keeping of the core culture of the northern territories. One of them is the lack of music (or archive fund of theoretical and performing editions) for the preservation of cultural values. The second is the need to strengthen the participation of national leaders of culture in the process of preservation, revival and development of new ways of traditional musical culture, keeping the foundations of folk songs, intonation and national melodies. The third need is the appearance of its own experimental school workshops of unique personalities of the Northern Territories for pupils and students of the Higher School of Music, as in the main workshops of the European and Russian experts translate the cultural traditions of the civilized world, and it minimize the ethnospreserving and ethnos-forming processes. In turn, the cultural exchange with the indigenous peoples of the north by a professional classical music art contributes to the "likeness" and the integration of cultures. The state cultural policy assists in maintaining the traditional cultural identity of the peoples of the circumpolar area; it is necessary to change the focus of creating cultural and educational conditions for creation of basic conditions for the preservation of the national culture of the northern region. This is possible through the formation of professional musical art based on national traditions; video and audio preservation of Yakut professional performance; improving the work of musical institutions at local and regional levels.

\section{References}

1. Abramova M.A. (2003). Gumanisticheskiye predstavleniya v kul'ture narodov Yakutii [Humanistic representation in the culture of the peoples of Yakutia]. Ministry of Education, Yakutia State University named after M.K. Ammosov. Moscow, 216 p.

2. Abramova M.A. (2003). Idei gumanizma v kul'ture i obrazovanii Yakutii [The ideas of humanism in culture and education in Yakutia]. Yakutsk, $140 \mathrm{p}$.

3. Alekseeva G.I. (2008). Obrazovatel'noye prostranstvo profil'nogo obucheniya v Respublike Sakha (Yakutiya). [Educational space of Special Education in the Republic of Sakha (Yakutia)]. Sibirskiy pedagogicheskiy zhurnal (Siberian Education Journal), (5), 180-196.

4. Andreeva S. (2012). Detyam Yakutii - prazdniki sporta, nauki i kul'tury [Children Yakutia Holidays Sports, Science and Culture]. Rodina (Motherland) (12), 58-59.

5. Antonov E.P. (2013). Rossiya v samoidentifikatsii Yakutskoy intelligentsii [Russian identity in Yakut intellectuals]. Izvestiya Irkutskogo gosudarstvennogo universiteta. Seriya: Istoriya (Proceedings of Irkutsk State University. Series: History) (1), 62-71. 
6. Atlasova M.M. (2010). Regionalizatsiya soderzhaniya uchebnogo materiala - vazhneyshiy faktor osvoyeniya natsional'noy kul'tury $\mathrm{v}$ uchrezhdeniyakh obshchego obrazovaniya. [Regionalization of the content of teaching material - a key factor in the development of national culture in general education institutions]. Vestnik Moskovskogo gosudarstvennogo universiteta kul'tury i iskusstv (Bulletin of Moscow State University of Culture and Arts) (3), 162-168.

7. Borisova Yu.S. (2013). Obobshchennyy prognoz protsessov sokhraneniya yazykov i kul'tury korennykh narodov Yakutii v period do 2050g. [The generalized forecast processes preserve the languages and cultures of indigenous peoples of Yakutia in the period up to 2050]. Global'nyy nauchnyy potentsial (Global scientific potential), 7 (28), 10-14.

8. Bourtsev A.A. (2006). Rol' fenomenov kul'tury v imidzhirovanii Respubliki Sakha (Yakutiya). [The role of cultural phenomena in the image-representation of Republic of Sakha (Yakutia)]. Vestnik Severo-Vostochnogo federal'nogo universiteta im. M.K. Ammosova (Bulletin of the North-Eastern Federal University named after M.K. Ammosov), 3 (2), 74-77.

9. Vasilyeva N.D. (2011). Kul'tura korennykh narodov severa Yakutii v 1920-50-kh gg. [Indigenous culture of the north of Yakutia in 1920-50-ies]. Sborniki konferentsiy NITS Sotsiosfera (Collections Conference SIC Sociosphere), (29), 85-87.

10. Vasilyeva N.D. (2011). Formirovaniye sotsiokul'turnogo prostranstva Arktiki v kontekste mezhtsivilizatsionnogo vzaimodeystviya (na primere Yakutii). [Formation of the socio-cultural space of the Arctic in the context of inter-civilizational interaction (for example, Yakutia)]. Arktika i Sever (Arctic and North), (3), 96-104.

11. Vasilyeva S.P. (2012). Obrazovatel'naya praktika po sokhraneniyu kul'tury i yazyka Sakha i malochislennykh narodov RS (Yakutiya) : tekhnologii obrazovaniya, rezul'taty i effekty. [Educational practices for the conservation of culture and language Sakha and Indigenous Peoples of the RS (Yakutia): Technology Education, the results and effects]. Pedagogicheskoye obrazovaniye i nauka (Teacher's education and science) (8), 97-100.

12. Vinokourov E.P. (2008). Deti Yakutii kak sub»yekty mezhdunarodnoy kul'turnoy deyatel'nosti. [Children of Yakutia as subjects of international cultural activities]. Izvestiya Rossiyskogo gosudarstvennogo pedagogicheskogo universiteta im. A.I. Gertsena (Proceedings of the Russian State Pedagogical University named after A.I. Herzen), (69), 362-364.

13. Vinokourov E.P. (2008). Kul'turnyye vozmozhnosti etnosa.[Ethnic cultural opportunities]. Izvestiya Rossiyskogo gosudarstvennogo pedagogicheskogo universiteta im. A.I. Gertsena (Proceedings of the Russian State Pedagogical University named after A.I. Herzen), (70), 122-125.

14. Vinokourov U.A. (2011). Federal'nyye gosudarstvennyye obrazovatel'nyye standarty i etnokul'turnoye obrazovaniye. [Federal state educational standards and ethno-cultural education]. Nauka i obrazovaniye (Science and Education), (2), 38-41.

15. Golomareva E.Kh., Romanov N.N. (2010). Preyemstvennost' podkhodov v individualizatsii obucheniya $v$ usloviyakh kompleksnoy modernizatsii obrazovaniya. [Continuity in the individualization of learning approaches in a comprehensive modernization of education]. Profil'naya shkola (Profile school), (5), 12-17.

16. Golomareva E.Kh., Romanov N.N. (2012). Semeynoye vospitaniye detey-evenkov. [Family upbringing among the Evenks]. Narodnoye obrazovaniye (People's Education), (8), 274-278. 
17. Degtyareva V.G. (2011). Fenomen mistitsizma v kul'ture i iskusstve povsednevnosti (na materialakh Respubliki Sakha(Yakutiya)). [The phenomenon of mysticism in art and culture of everyday life (on the materials of the Republic of Sakha (Yakutia)). Vestnik Orlovskogo gosudarstvennogo universiteta. Seriya: Novyye gumanitarnyye issledovaniya (Bulletin of Oryol State University. Series: New Studies in the Humanities), 6 (20), 279-282.

18. Donskoy F.S., Robbek V.A., Scheikin Y.I., Donskoy R.I., Popova A.G. (2003). Integratsiya korennykh malochislennykh narodov Sibirskogo severa i Dal'nego Vostoka v obshcherossiyskuyu kul'turu. [Integration of Indigenous Peoples of the North Siberian and the Far East in the allRussian culture]. Rabota vypolnena v ramkakh proyekta 20.1 «Etnokul'turnoye vzaimodeystviye narodov Yevrazii» Integratsionnoy programmy prezidiuma RAN / Rossiyskaya Akademiya nauk, Sibirskoye otdeleniye, Institut probem malochislennykh narodov Severa; Otvetstvennyy redaktor akademik Mezhdunarodnoy akademii agrarnogo obrazovaniya i Akademii Severnogo Foruma, doktor ekonomicheskikh nauk, professor Tikhonov N.N. Retsenzenty: doktor ekonomicheskikh nauk Vasil'yev YA.T., kandidat filosofskikh nauk Tobukov P.Z (The work was completed in the framework of the project 20.1 «Ethno-cultural interaction peoples of Eurasia» Integration Program of the Presidium of the RAS / Russian Academy of Sciences, Siberian Branch, Institute of troubleshooting any problems numerically small peoples of the North; Managing editor of the International Academy of Agricultural Education and the Northern Forum Academy, Doctor of Economics, Professor N. Tikhonov Reviewers: Doctor of Economics Vasilev Ya.T., PhD Tobukov P.Z.), Yakutsk,. 396p.

19. Drobizheva L.M., Arutyunov E.M., Bravin A.D., Kuznetsov I.M., Pereboeva M.A., Ryzhov S.V., Yakovlev E.Ya. (2012). Identichnost' i konsolidatsionnyy resurs zhiteley Respubliki Sakha (Yakutiya). [Identity and resource consolidation residents of Republic of Sakha (Yakutia)]. Informatsionnoanaliticheskiy byulleten' Instituta sotsiologii Rossiyskoy akademii nauk (The information-analytical bulletin of the Institute of Sociology of the Russian Academy of Sciences), (04), 4-96.

20. Zakharov A.A. (2013). O putyakh sokhraneniya etnicheskoy samobytnosti natsional'nykh vidov sporta na sovremennom etape razvitiya. [Ways to preserve ethnic identity of national inputs sport at the present stage of development]. Uchenyye zapiski universiteta im. P.F. Lesgafta (Scientific notes of University named after P.F. Lesgaft), 2 (96), 66-69.

21. Ivanov A.V. (2009). Razvitiye polikul'turnogo obrazovaniya $\mathrm{v}$ istoriko-pedagogicheskom aspekte (na primere Respubliki Sakha (Yakutiya) [The development of multicultural education in the historical and pedagogical aspects (for example, the Republic of Sakha (Yakutia)). Sibirskiy pedagogicheskiy zhurnal (Siberian Education Journal), (7), 195-202.

22. Ivanov A.V. (2013). Kul'tura mezhnatsional'nykh otnosheniy v novykh obrazovatel'nykh programmakh. [Culture of international relations in the new educational programs]. Gumanitarnyye, sotsial'no-ekonomicheskiye $i$ obshchestvennyye nauki (Humanitarian, socio-economic, and social sciences), (7-1), pp.170-172.

23. Ignatieva S.S. (2013). Budushchaya kul'tura severa. [The future of the culture of the north]. Akkreditatsiya v obrazovanii (Accreditation in Education), 3 (63), 52-53.

24. Ilyin V.I. (2012). Mekhanizmy realizatsii gosudarstvennoy natsional'noy politiki v Rossiyskoy Federatsii. [Mechanisms for implementation of the state national policy in the Russian Federation]. Srednerusskiy vestnik obshchestvennykh nauk (Srednerussky Gazette of Social Sciences), (2), pp.105-116. 
25. Isakov N. Kul'tura narodov Severa: Filosofsko-sotsiologicheskiy analiz [Culture of peoples of the North: Philosophical and sociological analysis]. Novosibirsk, 1989, 156p.

26. Karlova O.A., Koptseva N.P., Kirko V.I., Reznikov K.V., Zamaraeva Y.S., Sertakova E.A., Kistova A.V., Moskvich Y.N., Viktoruk E.H., Viktoruk E.A., Tarasova M.V., Komaritsyn S.G., Pavlova I.P., Pavlov P.P., Shishatskiy N.G., Nevzorov V.N. Novoye budushcheye Sibiri: ozhidaniya, vyzovy, resheniya: [Siberia future expectations, challenges, solutions], Krasnoyarsk, 2013.

27. Karpov E.G. (2007). Yakutskaya kul'tury v kontekste prosvetitel'skoy deyatel'nosti. [Yakut culture in the context of education]. Mir obrazovaniya - obrazovaniye v mire (The world of educationeducation in the world) (1), pp.101-108.

28. Kirko V.I., Kopitsa A.L., Upatov A.V. (2013). Otsenka urovnya kachestva i polnoty okazaniya meditsinskoy pomoshchi na territorii Dolgano-Nenetskogo i Evenkiyskogo munitsipal'nykh rayonov Krasnoyarskogo kraya. [Assessment of the level of quality and completeness of medical care in the territory of Dolgan-Nenets and Evenk municipal districts of the Krasnoyarsk Region]. Sovremennyye problemy nauki i obrazovaniya (Modern problems of education and science), (2), 57.

29. Kirko V.I., Fatkulina-Yaskova L.M., Zaharyuta V.I. (2012). Otsenka tekhnicheskogo sostoyaniya ob"yektov poseleniy Evenkii i Taymyra. [Assessment of technical condition of the settlements of Evenkia and Taimyr]. Academia, (2), 115-123.

30. Kovrova O.D. (2008). Razvitiye regional'noy kul'turnoy politiki v tvorcheskikh proyektakh i tselevykh programmakh. [The development of regional cultural policy in creative projects and programs]. Izvestiya Rossiyskogo gosudarstvennogo pedagogicheskogo universiteta im. A.I. Gertsena (Proceedings of the Russian State Pedagogical University named after A.I. Herzen), (49), 71-73.

31. Kondratieva S.I. (2013). Otsenka vozmozhnostey novykh obrazovatel'nykh tekhnologiy sokhraneniya kul'tury, yazyka, ukladov zhizni korennykh narodov Respubliki Sakha (Yakutiya) [Evaluation of the potential of new educational technologies to preserve the culture, language and ways of life of indigenous peoples of the Sakha Republic (Yakutia)]. Obrazovaniye. Nauka. Innovatsii: Yuzhnoye izmereniye (Education. Science. Innovation: Southern Dimension), 6 (32), 71-79.

32. Koptseva N.P. (2012). Metodologicheskiye vozmozhnosti sotsial'noy (kul'turnoy) antropologii dlya sovremennykh kul'turnykh issledovaniy. [Methodological possibilities of social (cultural) anthropology of contemporary cultural studies]. Filosofiya i kul'tura (Philosophy and Culture) (10), 9-18.

33. Koptseva N.P. (2012). Problema metodologii sovremennykh kul'turnykh issledovaniy: vozmozhnosti klassicheskoy britanskoy sotsial'noy antropologii. [The problem of methodology of contemporary cultural studies: Opportunities classic British social anthropology]. Gumanitarnyye $i$ sotsial'nyye nauki (Humanities and Social Sciences), (4), 89-104.

34. Koptseva N.P. (2013). Provedeniye eksperimental'nogo prikladnogo kul'turnogo issledovaniya mezhkul'turnoy kommunikatsii: fokus-gruppy, lichnoye interv'yu, anketirovaniye, polucheniye ekspertnogo mneniya (na materiale issledovaniya Krasnoyarskogo kraya). [A pilot study of applied cultural intercultural communication: focus groups, personal interviews, questionnaires, obtaining expert opinion (based on studies of the Krasnoyarsk Region)]. Sovremennyye problemy nauki $i$ obrazovaniya (Modern problems of science and education), (3), 400-410.

35. Koptseva N.P., Sertakova E.A., Ilbeykina M.I., Reznikov K.V., Luza V.S., Zamaraeva Y.S., Libakova N.M., Semenova A.A. (2011). Kul'tura korennykh i malochislennykh narodov Severa v 
usloviyakh global'nykh transformatsiy [Culture of Indigenous Peoples of the North in terms of global transformations]. St. Petersburg, 174p.

36. (2012) Korennyye malochislennyye narody Severa i Sibiri v usloviyakh global'nykh transformatsiy (na materiale Krasnoyarskogo kraya). Chast' 1. Kontseptual'nyye i metodologicheskiye osnovy issledovaniya. Etnokul'turnaya dinamika korennykh malochislennykh narodov Krasnoyarskogo kraya [Indigenous peoples and minorities of the North and Siberia in the context of global transformations (on the material of the Krasnoyarsk Region). Part 1: Conceptual and methodological foundations of the study. Ethno-cultural dynamics of indigenous peoples of the Krasnoyarsk Region], Krasnoyarsk, 640 p.

37. Koryakina A.F. (2013). Formirovaniye mezhkul'turnoy kompetentsii detey i uchashcheysya molodezhi v usloviyakh nepreryvnogo polikul'turnogo obrazovaniya Respubliki Sakha (Yakutiya). [Formation of the intercultural competence of children and youth in continuous multicultural education of the Republic of Sakha (Yakutia)]. Filologicheskiye nauki. Voprosy teorii i praktiki (Philology. Theory and Practice), 3-1 (21), 73-78.

38. Kul'tura Respubliki Sakha (Yakutiya): lyudi, fakty, sobytiya (1953-2003 gg.) [Culture of the Republic of Sakha (Yakutia), people, facts, events (1953-2003gg.)]. Yakutsk, 2004.

39. Larionova A.G. (2000). Etnopedagogicheskiye osnovy formirovaniya muzykal'noy kul'tury mladshikh shkol'nikov (na primere shkol Respubliki Sakha (Yakutiya)). Dissertatsiya na soiskaniye uchenoy stepeni kandidata pedagogicheskikh nauk. [Ethno-pedagogical basis for the formation of musical culture of younger students (for example, schools in the Republic of Sakha (Yakutia)). Dissertation for the degree of candidate of pedagogical sciences]. Yakutsk, $166 \mathrm{p}$.

40. Larionova A.S. (2009). Rol' gosudarstvennosti Yakutii v razvitii muzykal'noy kul'tury naroda Sakha (V sbornike: Narody Yevrazii: problemy natsional'noy istorii (k 110-letiyu M.K. Ammosova) [The role of the state in the development of Yakutia musical culture of the people of Sakha (In: The peoples of Eurasia: Problems of national history (the 110th anniversary Ammosov)]. Materialy Mezhdunarodnoy nauchno-prakticheskoy konferentsii. Rossiyskaya akademiya nauk Sibirskoye otdeleniye, Institut gumanitarnykh issledovaniy i problem malochislennykh narodov Severa (International scientific and practical conference materials. Russian Academy of Sciences Siberian Branch, Institute of Humanitarian Research and Indigenous Peoples North), 186-192.

41. Lobok A.M. (2010). Yestestvennyye kul'turnyye dominanty Yakutskogo obrazovaniya. [Natural cultural dominants of Yakut education]. Novyye tsennosti obrazovaniya (New values of education), 46 (4), 33-49.

42. Makarova A.D. (2007). Kolledzh kul'tury i iskusstva Respubliki Sakha (Yakutiya) iz istorii obrazovaniya kolledzha kul'tury i iskusstva. [College of Culture and Arts of the Republic of Sakha (Yakutia) in the history of college education culture and art]. Sredneye professional'noye obrazovaniye (Secondary vocational education), (8), 33-34.

43. Marfusalova V.P. (2013). Etnokul'turnyye svyazi korennykh malochislennykh narodov severovostoka Rossii. [Ethno-cultural communication of Indigenous Peoples of the North-East of Russia]. Severo-Vostochnyy gumanitarnyy vestnik (Northeastern Humanities Bulletin), 1 (6), 40-45.

44. Mineev V.V. (2012). Yedinstvo teoretiko-metodologicheskikh i metodiko-prakticheskikh aspektov prepodavaniya filosofskikh distsiplin. [The unity of the theoretical, methodological and practical aspects of teaching philosophical disciplines]. Istoricheskiye, filosofskiye, politicheskiye 
i yuridicheskiye nauki, kul'turologiya i iskusstvovedeniye. Voprosy teorii i praktiki (Historical, philosophical, political and legal sciences, cultural studies and art history. Theory and Practice) (51), 123-127.

45. Mikhailova E.I. (2012). Prioritety razvitiya universiteta. [Development priorities of the university]. Sotsiologiya obrazovaniya (Sociology of Education), (3), 4-7.

46. Nikitin R.S., Vinokourov E.I.,. Ivanov A.V (2008). Novyye podkhody k formirovaniyu kul'turovedcheskoy kompetentsii $\mathrm{v}$ polikul'turnom obrazovatel'nom prostranstve Yakutii. [New approaches to cultural studies of competence in multicultural educational environment Yakutia]. Nauka i obrazovaniye (Science and Education), (4), 104-108.

47. Nikolaev A.D., Osipova O.P. (2012). Kul'turnaya paradigma kak osnova sotsiokul'turnoy modernizatsii regional'noy sistemy obrazovaniya. [Cultural paradigm as the basis socio-cultural modernization of the regional system of education]. Prepodavatel' 21 vek (Teacher $21^{\text {st }}$ Century), 1 (3), 49-51.

48. Panina S.V., Popova L.N., Zalutskaya S.Y. (2012). Sotsial'no-kul'turnaya missiya vuza: formirovaniye i sokhraneniye natsional'noy elity. [Socio-cultural mission of the university: the formation and preservation of the national elite]. European Journal of Social Sciences, (7), 66-73.

49. Petrova M.P. (2011). Dopolnitel'noye obrazovaniye detey Respubliki Sakha (Yakutiya): modeli razvitiya $\mathrm{v}$ istoricheskom rakurse. [Additional education of the children of the Republic of Sakha (Yakutia): model development in historical perspective]. Nauka i obrazovaniye (Science and Education) (1), 90-94.

50. Pokatilova I.V. (2013) Khudozhestvennaya kul'tura Yakutii v sotsiokul'turnoy situatsii na rubezhe XX-XXI vv. [Art culture of Yakutia in sociocultural situation at the turn of XX-XXI centuries]. Yakutsk, North-Eastern Federal University named after Ammosov, 709-717.

51. Popova L.N. (2013). K voprosu o budushchem natsional'noy kul'tury (opyt forsaytissledovaniya $\mathrm{v}$ Respublike Sakha (Yakutiya). [On the question of the future of the national culture (experience foresight studies in the Republic of Sakha (Yakutia)] Vestnik ekonomiki, prava i sotsiologii (Bulletin of economics, law and sociology), (3), 228-231.

52. Popova L.N., Panina S.V. (2012). Formirovaniye etnokul'turnogo samoopredeleniya lichnosti $\mathrm{v}$ obrazovatel'noy srede. [Formation of ethnic and cultural identity of the person in the educational environment]. Sotsiologiya obrazovaniya (Sociology of Education), (8), 86-95.

53. Prokopeva M.M. (2007). Etnopedagogicheskoye obespecheniye sistemy semeynoy samoorganizatsii yakutov. [Ethno-pedagogical support of the system of the family self-organizationf of Yakuts]. Pedagogika (Pedagogy), (6), 98-106.

54. Prokopeva M.M., Vasilieva T.G. (2012). Etnopedagogizatsiya samoorganizatsii sem'i severnykh narodov kak sotsiokul'turnyy fenomen [Ethnic-pedagogic self-organization in families of the northern people as a sociocultural phenomenon]. 16 (2), 7-11.

55. Pylneva L.L. (2009). Natsional'nyye kompozitorskiye shkoly Sibiri: k postanovke problemy. [National composer schools of Siberia: stipulating the problem]. Gumanitarnyye nauki $v$ Sibiri (Humanities in Siberia), (3), 124-127.

56. Pylneva L.L. (2010). Istoriograficheskiye problemy izucheniya natsional'nykh kompozitorskikh shkol Sibiri. [Historiographical problems in the study of national schools of composition in Siberia]. Gumanitarnyye nauki v Sibiri (Humanities in Siberia), (3), 92-96. 
57. Pylneva L.L. (2012). Muzykal'naya kul'tura Buryatii, Tuvy i Yakutii v 1990-2000-ye gg. Idei $\mathrm{i}$ ideally [Musical Culture of Buryatia, Tuva and Yakutia in 1990-2000-ies. Ideas and ideals] 2 (1), 137144.

58. Pylneva L.L. (2012). O rannem etape tvorchestva kompozitorov v Respublikakh Sibiri. [On the early stage of composers in the Republics of Siberia]. Aktual'nyye problemy vysshego muzykal'nogo obrazovaniya (Topical problems of higher music education), 4 (25), 31-38.

59. Savvinov V.M. (2013). Otsenka sushchestvuyushchikh obrazovatel'nykh praktik, napravlennykh na sokhraneniye i vosproizvodstvo kul'tury i yazyka korennykh narodov Respubliki Sakha (Yakutiya). [Evaluation of existing educational practices aimed at the preservation and reproduction of culture and language of the indigenous peoples of the Sakha Republic (Yakutia)]. Obrazovaniye. Nauka. Innovatsii: Yuzhnoye izmereniye (Education. Science. Innovation: Southern Dimension), 6 (32), 105-116.

60. Semenova A.D., Vinokourova U.A., Yadrihinskaya L.S. (2012). Etnopedagogicheskiy mekhanizm formirovaniya universal'nykh uchebnykh deystviy obuchayemykh [Ethno-pedagogical formation mechanism of action of the universal education of trainees]. European Journal of Social Sciences, (2), 38-46.

61. Sivtseva A.A. (2007). Model' formirovaniya tsennostnykh oriyentatsiy u studentov mladshikh kursov. [Model for the formation of value orientations in younger students]. Izvestiya Rossiyskogo gosudarstvennogo pedagogicheskogo universiteta im. A.I. Gertsena (Proceedings of the Russian State Pedagogical University named after A.I. Herzen), 11 (32), 389-392.

62. (2011) Sokrovishcha kul'tury Yakutii. [Treasures of the culture of Yakutia]. [Ministry of Culture and Spiritual Development of Sakha (Yakutia), the Institute of Humanitarian Research and Indigenous Peoples of the North SB RAS]. Ser. 14 Naslediye narodov Rossiyskoy Federatsii. [Series 14 Legacy of the peoples of the Russian Federation]. Moscow

63. Spiridonov I.E. (1996). Mezhetnicheskoye vzaimodeystviye i professional'naya khudozhestvennaya kul'tura: istoriko-sotsiologicheskiy aspekt: na materiale Respubliki Sakha (Yakutiya) [Interethnic interaction and professional artistic culture: historical and sociological aspect: on the material of the Republic of Sakha (Yakutia). [Abstract of dissertation for the degree of candidate of sociological sciences]. St. Petersburg, $19 \mathrm{p}$.

64. Stepanova (2007). Kontseptual'noye obosnovaniye formirovaniye etnokul'turnoy kompetentnosti rebenka v polikul'turnoy srede doshkol'nogo obrazovatel'nogo uchrezhdeniya. [Conceptual justification and formation of the ethno-cultural competence of the child in a multicultural environment of preschool educational institution]. Nauka i obrazovaniye (Science and Education) (1), 106-110.

65. Sulejmanov A.A. (2009). Korennyye narody arkticheskoy zony Yakutii i mezhdunarodnoye nauchnoye sotrudnichestvo: 90-ye gg. XX v. [The indigenous peoples of the Arctic zone of Yakutia and international scientific cooperation: 90 -ies of the 20th century]. Nauchnyye problemy gumanitarnykh issledovaniy (Scientific problems of Humanitarian Studies), (122), 115-123.

66. Tereshkina G.D. (2012). Profil'noye obucheniye v shkolakh malochislennykh narodov severa Respubliki Sakha (Yakutiya). [Specialized education in the schools of small peoples of the north of the Republic of Sakha (Yakutia)]. Nauka i obrazovaniye (Science and Education), (2), 127-133.

67. (2003) Upravleniye razvitiyem kul'tury Respubliki Sakha (Yakutiya).[Managing the development of culture of the Republic of Sakha (Yakutia)]. Yakutsk, 48 p. 
68. Ushakov D.V., Abramova M.A., Kostyuk V.G. (2011). Etnicheskaya identichnost' kak sotsiokul'turnyy oriyentir v mezhetnicheskikh otnosheniyakh. [Ethnic identity as a social and cultural landmark in inter-ethnic relations]. Vestnik Novosibirskogo gosudarstvennogo universiteta. Seriya: Filosofiya (Bulletin of the Novosibirsk State University. Series: Philosophy), 9 (3), 91-98.

69. Fiklistova O.O. (2008). Regionalizatsiya obrazovaniya kak podkhod v obuchenii. [Regionalization of education as an approach to learning]. Nauka i obrazovaniye (Science and Education) (2), 23-25.

70. Flegontova U.M. (2011). Dialog literatur - put' k dukhovnomu vzaimoponimaniyu narodov., [Dialogue Literature - the path to spiritual understanding among the peoples]. Sibirskiy pedagogicheskiy zhurnal (Siberian Education Journal), (12), 228-234.

71. Fridovsky V., Kuzmina R.A. (2010). Vklad vuzovskogo sektora nauki v intellektual'noye obespecheniye uskorennogo razvitiya regiona. [The contribution of higher education sector in science intellectual support accelerated development of the region]. Vestnik Severo-Vostochnogo federal'nogo universiteta im. M.K. Ammosova (Bulletin of the North-Eastern Federal University. Named after M.K. Ammosov), 7 (1), 5-15.

72. (2009) Khudozhestvennoye obrazovaniye v kul'turnom prostranstve Arktiki. [Art education in the cultural space of the Arctic]. Materialy Mezhdunarodnoy nauchno-prakticheskoy konferentsii (International scientific and practical conference). Yakutsk, $319 \mathrm{p}$.

73. Scheikin Y.I. (2002) Istoriya muzykal'noy kul'tury narodov Sibiri [The history of musical culture of the peoples of Siberia]. Comparative-historical research / Russian Academy of Sciences, Siberian Branch, Institute of Indigenous Peoples of the North. Moscow, $718 \mathrm{p}$.

74. Scheikin Y.I. Muzykal'naya kul'tura narodov Sibiri (sravnitel'no-istoricheskoye issledovaniye instrumentov, zvukopodrazhaniy i pesen [Musical culture of the peoples of Siberia (comparativehistorical research tools, onomatopoeia and songs). Dissertation for the degree of Doctor of Arts / Russian Institute of Art History. St. Petersburg, 2002. 356.

75. Shilova V.N. (2010). Spetsifika etnokul'turnogo vospitaniya lichnosti v uchrezhdeniyakh kul'tury: lichnostno-oriyentirovannyy podkhod (na primere Respubliki Sakha (Yakutiya)). [Specificity of the ethno-cultural education of the individual in cultural institutions, student-centered approach (by the example of the Republic of Sakha (Yakutia)). Vestnik Moskovskogo gosudarstvennogo universiteta kul'tury i iskusstv (Bulletin of Moscow State University of Culture and Arts) (4), 151-154.

76. Everstova M.K. (2009). Vospitaniye ekologicheskoy kul'tury uchashchikhsya na osnove traditsiy i obychayev narodov Yakutii. [Parenting ecological culture of pupils based on the traditions and customs of the peoples of Yakutia]. Vestnik Severo-Vostochnogo federal'nogo universiteta im. M.K. Ammosova (Bulletin of the North-Eastern Federal University named after M.K. Ammosov), 6 (4), 73-77.

77. (2005) Entsiklopediya korennykh malochislennykh narodov Severa, Sibiri i Dal'nego Vostoka Rossiyskoy Federatsii Encyclopedia of Indigenous Peoples of the North, Siberia and Far East of the Russian Federation. Moscow, 464 p.

78. (2011) Entsiklopediya kul'tury i iskusstva Yakutii. Encyclopedia of Culture and Art of Yakutia. Yakutsk, $27 \mathrm{p}$.

79. Yakovleva O.G. (2010). Natsional'naya shkola v Respublike Sakha(Yakutiya): istoriya, sovremennost' i tendentsii razvitiya. [National School in the Republic of Sakha (Yakutia): Past, Present, and development trends]. Nauka i obrazovaniye (Science and Education), (2), 40-44. 


\section{Феноменологическое описание классической музыки как этнообразующего элемента якутской культуры}

Ю.С. Замараева

Сибирский федеральный университет Россия, 660041, Красноярск, пр. Свободный, 79

Классическое профессиональное музыкальное искусство Якутии стало ярким самобытным художественным явлением с 1990-х годов. Данный факт указывает, что профессиональное музыкальное искусство Якутии является сравнительно молодой музыкальной культурой. В данной статье на материале анализа источников по истории классической музыки и исследования современного состояния классического музыкального искусства выявлены специфические черты классической музыки как этнообразующего элемента якутской культуры. Между тем назрела существенная необходимость исследования данной области в настоящее время, по мнению ученых, фундаментальных (аналитических и обобщающих) исследований по музыкальной культуре почти не существует. На сегоднямний день имеется ряд сущностных потребностей в усилении выработки собственных механизмов самообразования и самосохранения ядра культуры северных территорий. В заключение даны рекомендации в области государственной культурной политики, осуществляющей помощь в сохранении самобытных культурных традиций народов циикумполярных территорий.

Ключевые слова: музыкальная культура Якутии, культурные исследования, культурология, этнос.

Научная специальность: 24.00.00 - культурология, 17.00.00-искусствоведение. 